\title{
Fertiliser requirements for peat soils in the Waikato region
}

\author{
M.B. O'CONNOR ${ }^{1}$, R.D. LONGHURST ${ }^{1}$, T.J.M. JOHNSTON ${ }^{2}$ and F.N. PORTEGYS \\ ${ }^{1}$ AgResearch, Ruakura, Private Bag 3123, Hamilton \\ ${ }^{2}$ Ballance Agri-Nutrients Limited, Private Bag12503, Mt Maunganui South \\ mike.oconnor@agresearch.co.nz
}

\begin{abstract}
Peat soils cover approximately 94000 ha of productive land in the Waikato and are an important soil resource for the region. Much of the research on peats in the $1950 \mathrm{~s}-60 \mathrm{~s}$ concentrated on the development of raw peats and later in the 1970 s on nutrient deficiencies such as copper and selenium. Little to no work was undertaken on soil fertility/soil nutrient relationships of developed peat soils. In 1996, a series of eight field trials was established across a range of developed peat soils in the Waikato to investigate such relationships. The trials continued for 3 years. Results showed that the optimum Olsen P soil test for sustaining near maximum pasture production was $35-45$, that $\mathrm{K}$ soil tests were of limited use on well developed peats and that winter leaching of S was likely to be important. The Anion Storage Capacity (ASC) test was found to be a valuable tool in indicating the degree of development of peat and in turn allowing interpretation of fertiliser responses. From these introductory investigations of nutrient requirements on peat soils some guidelines and recommendations are presented.
\end{abstract}

Keywords: anion storage capacity (ASC), Olsen $\mathrm{P}$, pasture production, peat, soil test

\section{Introduction}

The total area of organic soils in New Zealand is estimated at 200000 ha (Gibbs 1980). In the Waikato, peat soils cover about 94000 ha with $80 \%$ of the area now developed into agriculture and horticulture (Environment Waikato 1999). Developed peat soils are highly productive and can achieve annual herbage yields similar to mineral soils, although growth in late winter/early spring can be lower due to more severe $\mathrm{N}$ deficiency (Baars 1988). A wide range of horticultural crops are grown on peat soils, including squash, blueberries, potatoes and onions and some of the highest yields of maize in New Zealand have been recorded on peat soils (Graeme Austin, pers. comm.).

Although peat soils are an important soil resource in the Waikato, very little research has been undertaken on them since the 1950-60s (Thompson \& Elliott 1950; van der Elst 1958, 1962; van der Elst \& Watkinson 1972). Information on target soil nutrient ranges and the fertiliser inputs required to raise the soil fertility status of major elements for peat soils has not been available. In early 1996, with financial assistance from Ballance Agri-Nutrients Ltd, AgResearch commenced field studies on the major peat soils of the Waikato with the objective of developing soil test/pasture production relationships for phosphorus $(\mathrm{P})$, potassium (K), and sulphur (S).

\section{Methods}

\section{Trial location}

Eight field trials were laid down in May 1996 on sites covering the major peat soils of the Waikato region including the Hauraki, Rukuhia, Orini and Moanatuatua peat deposits (Davoren 1978) (Figure 1). The trial sites were selected to represent a range of development phases of peat soils under pasture at different levels of soil fertility. At the start of the trial organic carbon (C) measurements were taken to categorise the sites. Initially, changes in organic $\mathrm{C}$ content were expected to be the best indicator of peat development phase and certainly site differences were apparent (Table 1). However Anion Storage Capacity (ASC) gave a better spread of values and was felt to be a more appropriate test to use. The ASC test is a measure of the soil's ability to store phosphate $(\mathrm{P})$ and was previously known as the P retention test (Saunders 1965). Phosphate retention is related to the parent material of the soil and its chemical and microbiological composition. In the case of the Waikato peats, the associated parent material is andesitic volcanic ash with a very high ASC value. Trial sites were chosen across a wide range of Olsen P values with four sites each of low ASC $(<60 \%)$ and high ASC $(>60 \%)$ status. The arbitrary cut off point of 60 between high and low ASC was based on the spread over the eight sites (Table 1).

\section{Trial design and management}

Each trial site of 24 plots consisted of two replicates of six rates of $\mathrm{P}$, applied as triple superphosphate, $(0,15$, $30,60,90$, and $120 \mathrm{~kg} / \mathrm{ha} / \mathrm{annum}$ ); one replicate of six rates of potassium $(\mathrm{K})$, applied as muriate of potash, 
$(0,20,40,60,80$, and $100 \mathrm{~kg} / \mathrm{ha} /$ annum $)$; and one replicate of six rates of S, applied as gypsum, $(0,10,20$, 40,60 , and $80 \mathrm{~kg} / \mathrm{ha} /$ annum). Fertiliser treatments were randomised within each block of six plots. The trials were conducted under a continuous cutting regime to $3 \mathrm{~cm}$ height and annual production was measured over six to nine cuts. The "mowing and clippings returned" technique (Lynch 1966) was used with approximately $40 \%$ of each harvest returned to the plots. Soil samples $(0-7.5 \mathrm{~cm})$ were taken initially and at the end of each year and analysed for the respective element of particular interest for that plot, i.e., P, K, or S.

Fertiliser treatments were applied during May each year along with a basal trace element mix. Each fertiliser treatment received basal fertiliser dressings of the other two major elements, for example, $\mathrm{P}$ treatments received $\mathrm{K}(100 \mathrm{~kg} / \mathrm{ha})$ and $\mathrm{S}(30 \mathrm{~kg} / \mathrm{ha})$, while $\mathrm{P}$ basal dressings of $50 \mathrm{~kg} / \mathrm{ha}$ were applied to $\mathrm{K}$ and $\mathrm{S}$ plots. Both $\mathrm{K}$ (muriate of potash) and $\mathrm{S}$ (gypsum) fertilisers were applied as split dressings in May and November.

\section{Statistical analysis}

Each trial site was treated as one replicate for statistical purposes. Pasture yields and soil data were subject to analysis of variance. Soil data were log transformed to stabilise the variance, with back-transformed means scaled so that their mean equalled those of the untransformed means and are presented in the tables. In these situations, the least significant ratio (LSR) has been used as the test for significance.

\section{Results and discussion}

\section{Peat development}

Organic soils are classified as those with more than $20 \%$ organic carbon in the topsoil (Taylor \& Pohlen 1970). Peats are separated from peaty loams on the basis that they have more than $40 \%$ organic carbon. The cultivation of peat leads to a decline in carbon
Figure 1 Map of Waikato showing the major peat areas and location of trial sites

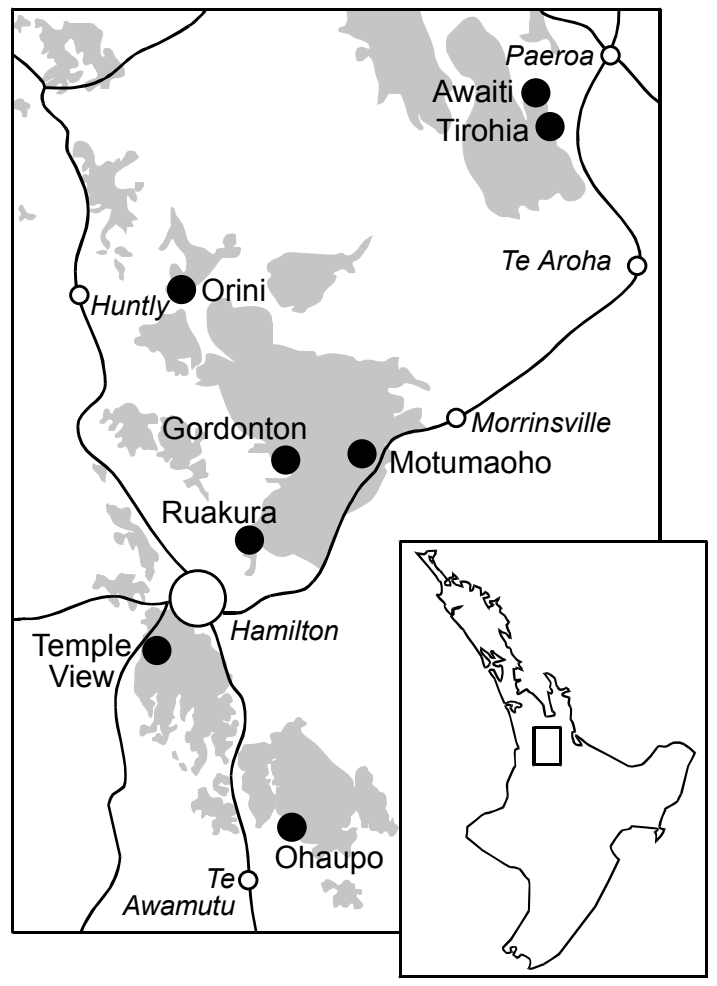

content as it is oxidised to carbon dioxide. This process continues as the peat mineralises and matures. Organic carbon ranged between $21-37 \%$ for the high and low ASC sites (Table 1).

Unlike for mineral soils, the anion storage capacity (ASC) of organic soils increases as peat is developed from a 'raw' state, through drainage and cultivation over time, to the 'developed' stage. As the carbon content falls, the mineral content increases which leads to an increase in the ASC value. The mineral content

Table 1 Soil chemical characteristics $(0-75 \mathrm{~mm})$ of individual trial sites at start of experiment.

\begin{tabular}{|c|c|c|c|c|c|c|c|}
\hline Trial Location & $\mathrm{pH}$ & $\mathrm{P}$ & $\mathrm{K}$ & $\begin{array}{c}\text { Sulphate } \\
\text { S }\end{array}$ & $\begin{array}{c}\text { Organic } \\
\mathrm{S}\end{array}$ & ASC & $\begin{array}{c}\text { Org. C } \\
(\%)\end{array}$ \\
\hline \multicolumn{8}{|l|}{ Low-ASC } \\
\hline Temple View & 5.2 & 27 & 7 & 7 & 6 & 29 & 36.0 \\
\hline Orini & 5.2 & 36 & 13 & 13 & 8 & 38 & 37.2 \\
\hline Awaiti & 5.2 & 52 & 11 & 19 & 10 & 52 & 30.0 \\
\hline Gordonton & 5.1 & 60 & 15 & 79 & 9 & 58 & 36.0 \\
\hline Mean & 5.2 & 44 & 12 & 30 & 8 & 44 & 34.5 \\
\hline \multicolumn{8}{|l|}{ High ASC } \\
\hline Tirohia & 5.4 & 60 & 5 & 17 & 11 & 86 & 21.2 \\
\hline Ruakura & 5.2 & 18 & 4 & 4 & 9 & 72 & 28.0 \\
\hline Ohaupo & 5.6 & 23 & 5 & 29 & 10 & 83 & 22.0 \\
\hline Motumaoho & 5.9 & 27 & 2 & 18 & 11 & 89 & 33.6 \\
\hline Mean & 5.5 & 32 & 4 & 17 & 10 & 83 & 26.2 \\
\hline
\end{tabular}


in many Waikato peats is volcanic ash containing allophanic clays. This appears originally as thin layers within the peat profile of predominantly deep peats (Davoren 1978). The ASC test is therefore seen as a good indicator of stage of development of peat in the Waikato region. As a general rule of thumb, low ASC sites $(<60 \%)$ could be considered as those that have been developed less than 15-20 years while high ASC sites $(>60 \%)$ would likely be those with $>20$ years development. However, there are likely to be exceptions to this for reasons as yet not understood.

\section{Phosphorus - pasture and soil}

Herbage responses to rates of $\mathrm{P}$ across the low and high ASC sites are given in Table 2. Annual herbage production on the high ASC sites ranged from 10.5$11.4 \mathrm{t} \mathrm{DM} /$ ha compared to $8.5-10.9 \mathrm{t} \mathrm{DM} / \mathrm{ha}$ for low ASC sites. When expressed in relative terms to control, the average herbage responses were small $(<6 \%)$ on both the low and high ASC sites.

There were significant $(\mathrm{P}=0.015)$ increases in Olsen $\mathrm{P}$ soil concentrations from the increased $\mathrm{P}$ inputs (Table 2). For a given input of $P$ the increase in Olsen $\mathrm{P}$ was significantly $(\mathrm{P}<0.001)$ greater on the high ASC sites compared to low ASC sites.

\section{Target Olsen $P$ tests}

Soil data from the 3 years of trial results were used to obtain the optimum Olsen P soil value. For $97 \%$ of maximum pasture production, an Olsen $\mathrm{P}$ of 40 with a range of 35-45 was required (Figure 2). This is similar to the Olsen P target levels for pumice soils (Roberts \& Morton 1999). However, the amount of P fertiliser required to raise the Olsen $P$ soil test by 10 units varies according to the ASC status of the site (Table 3). Substantially higher amounts of $\mathrm{P}$ are required at a low ASC compared to a high ASC status. The reason for the higher $\mathrm{P}$ requirements at low ASC is unclear. Possible reasons are that $\mathrm{P}$ is being leached or that it has become immobilised by being organically bound. Leaching experiments or P fractionation studies would be required to determine exactly how $\mathrm{P}$ is disappearing. To minimise P loss particularly in the development/ redevelopment situation where high $\mathrm{P}$ inputs are required, it is suggested that $\mathrm{P}$ applications should be split into two to three applications during the year.

Trial results showed that once the desired Olsen $\mathrm{P}$ status was achieved, the amount of $\mathrm{P}$ required to maintain the Olsen $P$ level was approximately the same irrespective of ASC value. (Table 3).

\section{Potassium - pasture and soil}

Although there was a trend for the high ASC sites to produce more herbage than the low ASC sites, these
Table 2 Effect of rate of applied $\mathrm{P}$ on pasture production (mean of 3 years) and Year 3 soil Olsen P concentrations ( $\mathrm{mg} / \mathrm{ml})$.

\begin{tabular}{|c|c|c|c|c|c|c|}
\hline \multirow[b]{2}{*}{ ASC } & \multicolumn{6}{|c|}{----------- Applied P (kg/ha) } \\
\hline & 0 & 15 & 30 & 60 & 90 & 120 \\
\hline \multicolumn{7}{|l|}{$\mathrm{DM}(\mathrm{kg} / \mathrm{ha})$} \\
\hline Low ASC & 9200 & 9420 & 9610 & 9670 & 9740 & 9600 \\
\hline \multirow[t]{2}{*}{ High ASC } & 10820 & 10900 & 10860 & 11300 & 11150 & 11230 \\
\hline & \multicolumn{6}{|c|}{ LSD (5\%): within rows: 520 ; between rows: 2200} \\
\hline \multicolumn{7}{|l|}{ Olsen $\mathrm{P}$} \\
\hline Low ASC & 26 & 30 & 39 & 52 & 52 & 69 \\
\hline High ASC & 31 & 39 & 42 & 71 & 82 & 107 \\
\hline \multicolumn{7}{|c|}{ LSR (5\%): within and between rows: 1.26} \\
\hline
\end{tabular}

Figure 2 Response curve showing the relationship between relative pasture production and Olsen $\mathrm{P}$ for eight Waikato peat trial sites.

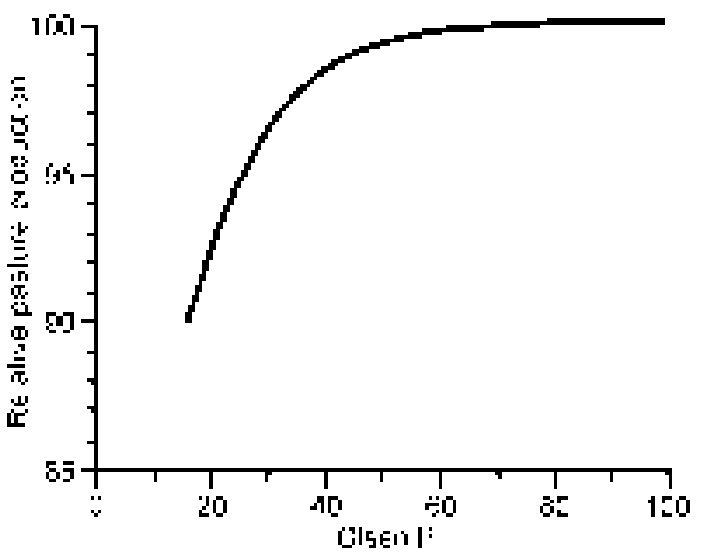

Table 3 Guidelines for amount of $P$ required to raise and maintain soil Olsen P ( $\mathrm{mg} / \mathrm{ml})$ status of developed peats.

\begin{tabular}{lcc}
\hline $\begin{array}{l}\text { ASC } \\
\text { rating }\end{array}$ & $\begin{array}{c}\text { Amount of P required to } \\
\text { raise Olsen } \mathrm{P} \text { by 10 units } \\
\mathrm{kg} \mathrm{P} / \mathrm{ha}\end{array}$ & $\begin{array}{c}\text { Amount of } \mathrm{P} \text { required } \\
\text { to maintain Olsen } \mathrm{P} \\
\mathrm{kg} \mathrm{P} / \mathrm{ha}\end{array}$ \\
\hline Low $(<60 \%)$ & 90 & 40 \\
High $(>60 \%)$ & 60 & 35 \\
\hline * The amount of $\mathrm{P}$ required will be modified according to stocking rate \\
and production.
\end{tabular}

differences were not significant $(\mathrm{P}=0.348)$ due to the variation between sites (Table 4). Overall, there was a linear herbage response to rates of $\mathrm{K}(\mathrm{P}=0.023)$ that tended to flatten off above the $40 \mathrm{~kg} \mathrm{~K} / \mathrm{ha}$ rate.

\section{Target potassium soil test}

Soil $\mathrm{K}$ tests showed a highly significant $(\mathrm{P}<0.001)$ rise in soil $\mathrm{K}$ values on low ASC sites, but on the high ASC sites, for the same input of fertiliser $\mathrm{K}$, there was no increase in soil K (Table 4). This inability to raise soil $\mathrm{K}$ levels on high ASC sites as opposed to low ASC 
sites is of interest. A possible explanation for this is the dominance of $\mathrm{Ca}$ on the exchange sites in the high ASC situations as a result of large inputs of lime over time (10-15t/ha when cultivated). Even so, $\mathrm{K}$ in the pasture in such situations is known to be high. For example, a comparison of soil $\mathrm{K}$ and $\% \mathrm{~K}$ in the pasture on four of the trial sites in 1998/99 showed that for the two low ASC sites, the average soil $\mathrm{K}$ across five rates of $\mathrm{K}$ was 8 and the pasture $\%$ $\mathrm{K}$ was $3.28 \%$, while for the two high ASC sites, the average soil $\mathrm{K}$ was 4 and the pasture $\% \mathrm{~K}$ was $3.24 \%$. Therefore, in spite of a low K soil test on the high ASC site, pasture $\% \mathrm{~K}$ was more than adequate. In practice, this means in the development phase (low ASC), optimum soil K tests of 7-8 should be aimed for. However, on high ASC sites the $\mathrm{K}$ soil test is likely to remain stable at 3-4 in spite of applying $\mathrm{K}$ fertiliser. Practically this means the K soil test is of limited use and one must rely on applying a maintenance $\mathrm{K}$ fertiliser rate based on stocking rate/ farm production and using follow-up herbage analyses as an indicator of plant sufficiency. The AgResearch Overseer ${ }^{\mathrm{TM}}$ model would be useful in this respect. It is still recommended that $\mathrm{K}$ be applied in splitdressings: two-thirds in spring, one-third in autumn.

\section{Sulphur - pasture and soil}

There was a significant $(\mathrm{P}=0.023)$ trend of increased herbage production to rates of $\mathrm{S}$, but no effect $(\mathrm{P}=0.245)$ across high and low ASC sites (Table 5). Soil results from year 3 showed that up to the $40 \mathrm{~kg} \mathrm{~S} / \mathrm{ha}$ rate there was no difference in sulphate-S levels between ASC sites, however, at the higher application rates the differences between low and high ASC sites were significant $(\mathrm{P}=0.009)$.

\section{Target sulphate-sulphur soil test}

Organic-S levels taken at the start and end of the trial were low $(<10)$ on low ASC sites in particular (Table 1) indicating low $\mathrm{S}$ reserves in peat soils generally. Initial sulphate-S levels taken during the autumn were high $(>10)$ and tended to remain high in subsequent autumn samplings. However, in practice, most sulphate-S tests taken in the spring on peat soils are low, suggesting that sulphate leaching is occurring over this period. This would result in lower sulphate levels $(<10)$ in spring and could subsequently affect herbage growth. The target soil sulphate-S test should be 10-12. Soil sampling (for sulphate-S) should ideally be undertaken in spring to identify the lowest values likely. Pasture S analyses could also aid interpretation of adequacy of $S$ status.

In practice, the application of elemental $\mathrm{S}$ (in the form of a sulphur-superphosphate product) in the
Table 4 Effect of rate of applied K on pasture production (mean of 3 years) and soil $\mathrm{K}$ concentrations* (Year 3 ).

\begin{tabular}{|c|c|c|c|c|c|c|}
\hline \multirow[b]{2}{*}{ ASC } & ------ & \multirow[b]{2}{*}{20} & \multicolumn{2}{|c|}{ Applied P (kg/ha) } & \multirow[b]{2}{*}{80} & \multirow[b]{2}{*}{100} \\
\hline & 0 & & 40 & 60 & & \\
\hline \multicolumn{7}{|l|}{$\mathrm{DM}(\mathrm{kg} / \mathrm{ha})$} \\
\hline Low ASC & 9350 & 9380 & 10230 & 10080 & 9690 & 9960 \\
\hline \multirow[t]{2}{*}{ High ASC } & 10190 & 10370 & 11430 & 11420 & 11350 & 11720 \\
\hline & \multicolumn{6}{|c|}{ LSD (5\%): within rows: 690; between rows: 1960} \\
\hline \multicolumn{7}{|l|}{ Soil $\mathrm{K}$ test } \\
\hline Low ASC & 5.6 & 7.5 & 7.1 & 8.4 & 9.1 & 12.3 \\
\hline High ASC & 3.7 & 4.3 & 3.8 & 3.7 & 4.7 & 4.4 \\
\hline \multicolumn{7}{|c|}{ LSR (5\%): within and between rows: 1.28} \\
\hline
\end{tabular}

* soil $\mathrm{K}$ x $20 \mathrm{mg} / \mathrm{ml}$ of soil

Table 5 Effect of rate of applied S on pasture production (mean of 3 years) and soil sulphate-S concentrations* (Year 3).

\begin{tabular}{|c|c|c|c|c|c|c|}
\hline \multirow[b]{2}{*}{ ASC } & & \multicolumn{2}{|c|}{ Applied P (kg/ha) } & \multirow[b]{2}{*}{60} & \multirow[b]{2}{*}{80} \\
\hline & 0 & 10 & 20 & 40 & & \\
\hline \multicolumn{7}{|l|}{$\mathrm{DM}(\mathrm{kg} / \mathrm{ha})$} \\
\hline Low ASC & 8720 & 8950 & 8980 & 9490 & 9690 & 9310 \\
\hline High ASC & 10730 & 11090 & 11080 & 11040 & 11390 & 11080 \\
\hline
\end{tabular}

Soil $\mathrm{SO}_{4}-\mathrm{S}$

$\begin{array}{lllllll}\text { Low ASC } & 11 & 15 & 16 & 16 & 23 & 25\end{array}$

$\begin{array}{lllllll}\text { High ASC } & 14 & 11 & 14 & 24 & 53 & 41\end{array}$

LSR (5\%): within and between rows: 1.61

* $\mathrm{mg} / \mathrm{ml}$ of soil

autumn is advised to reduce potential for leaching compared to spring-applied sulphate. Under high leaching conditions, an alternate strategy is split applications of sulphate-S in autumn and spring (Wheeler \& Thorrold 1997).

\section{Conclusions}

Herbage production on the more developed peat soils can be similar to those on mineral soils (Baars 1988). These trials have also indicated good production levels (Table 2). Overall annual herbage responses to rates of $\mathrm{P}, \mathrm{K}$, and $\mathrm{S}$ were small. The ASC test should be considered essential for peat soils as it can indicate the stage of peat development which in turn influences the response to different elements. For the same input of $\mathrm{P}$ fertiliser, the Olsen $\mathrm{P}$ test was raised higher on high ASC sites than on low ASC sites. From these trials it is considered that target Olsen $\mathrm{P}$ tests for peat soils should be 35-45. Once such levels are reached, maintenance rates of $\mathrm{P}$ will be similar across all sites depending on the level of production and stocking rates. The target soil K test for low ASC sites is 7-8, while it was not possible (and indeed impractical) to raise $\mathrm{K}$ tests above 3-5 on high ASC sites. The target sulphate-S test should be 10-12 with soil sampling for $\mathrm{S}$ being 
undertaken in spring so that the effects of winter leaching can be identified. Low organic-S tests plus low spring sulphate-S tests indicate that pastures should receive autumn applications of sulphur-superphosphate or split autumn/spring dressings of sulphate-S, e.g., superphosphate.

\section{ACKNOWLEDGEMENTS}

We acknowledge Balance Agri-Nutrients Limited for their support and financial input to the programme. We thank the eight participating farmers: Jack Healy, Calvin Bracken, Stuart Davey, Jenny Parker, Ken MacLean, Murray Smith, Martyn Sing, and Warren Lee; and John Waller for statistical analysis.

\section{REFERENCES}

Baars, J.A. 1988. On-farm applications of software in planning grazing management. Proceedings of the New Zealand Grassland Association 49: 21-24.

Davoren, A. 1978. A survey of New Zealand peat resources. Water and Soil Technical Publication 14. $156 \mathrm{pp}$.

Environment Waikato. 1999. For Peat's Sake - Good management practices for Waikato Peat Farmers. $28 \mathrm{pp}$.

Gibbs, H.S. 1980. New Zealand Soils, an introduction. Oxford University Press, Wellington. 118 pp.
Lynch, P.B. 1966. Conduct of Field Experiments. New Zealand Department of Agriculture Bulletin No. 399. $154 \mathrm{pp}$.

Roberts, A.H.C.; Morton, J.D. 1999. Fertiliser use on New Zealand dairy farms. New Zealand Fertiliser Manufacturers Association. 37 pp.

Saunders, W.M.H. 1965. Phosphate retention by New Zealand soils and its relationship to free sesquioxides, organic matter and other soil properties. New Zealand Journal of Agricultural Research 8: 30-57.

Taylor, N.H.; Pohlen, I. J. 1970. Soil Survey Method. Soil Bureau Bulletin 25. 242 pp.

Thompson, F.B.; Elliott, I.L. 1950. The development of Waikato peat soils. New Zealand Journal of Science and Technology 31: 1-16.

Van der Elst, F.H. 1958. Problems in Development of Peat Soils. New Zealand Soil News 3: 73-85.

Van der Elst, F.H. 1962. Recent progress in peat research. Proceedings Ruakura Farmers Conference 14: 119-127.

Van der Elst, F.H.; Watkinson, J.H. 1972. Selenium deficiency on high moor peat soils in New Zealand. Proceedings $4^{\text {th }}$ International Peat Congress: 149164, Finland.

Wheeler, D.M.; Thorrold, B.S. 1997. Pasture yield responses to different sulphur fertiliser strategies and its application to modelling. Proceedings of New Zealand Grassland Association 59: 39-43. 